\title{
エネルギーの釣合に基づく履歴型ダンパー付鉄骨造骨組の地震応答予測 SEISMIC RESPONSE PREDICTION OF STEEL FRAMES WITH HYSTERETIC DAMPERS BASED ON ENERGY BALANCE
}

\author{
長谷川 隆*1, 西山 功*2, 向井昭義*3, 石原 直*4, 加 村久哉*5 \\ Takashi HASEGAWA, Isao NISHIYAMA, Akiyoshi MUKAI, \\ Tadashi ISHIHARA and Hisaya KAMURA
}

\begin{abstract}
This paper presents a seismic response prediction method for steel frames with hysteretic dampers. This method is based on energy balance and is able to predict the seismic response of frames with dampers yielding under an earthquake to occur several times during the life of buildings. In this method, the number $\left(d n_{1}\right)$ of equivalent cycles of plastic deformation in hysteretic dampers is utilized to predict earthquake response of frames with hysteretic dampers. In order to grasp the $d n_{1}$ values, earthquake response analysis of analytical frames with hysteretic dampers is carried out. And, the adequacy of seismic response prediction by this method is verified through a comparison with results of earthquake response analysis of three different story frames.
\end{abstract}

Keywords : seismic response prediction, hysteretic damper, energy balance, earthquake response analysis 地震応答予測, 履歴型ダンパー, エネルギーの釣合, 地震応答解析

\section{1.はじめに}

履歴型ダンパー付骨組の地震時における応答性状に関しては、こ れまでに、多くの地震応答解析による検討が行われ、履歷型ダン パーに、より多くのエネルギーを消費させることによって、骨組全 体の応答変形や柱、梁部材の損傷を小さくできることが明らかにさ れている1122)なと。一方、地震応答解析によらずに、履歴型ダンパー 付骨組の各層の損傷を簡便に予測しようとする研究もいくつか行わ れている。

原田、秋山 ${ }^{3)}$ は、エネルギーの釣合に基づく骨組の耐震設計法4) が、履歴型のエネルギー吸収要素を持つ多層骨組の損傷予測に対し

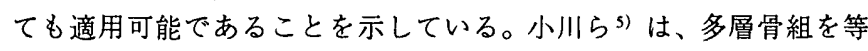
価 1 自由度系に置換して、1 自由度系の応答を予測し、その值から、 地震波毎に変化する骨組各層の平均的な応答值を予測する方法を示 している。辻井ら6)は、地震による骨組の総累積損傷エネルギーを 求め、スペクトルモーダル解析によって算定される最適降伏せん断 力分布を使って、そのエネルギーを各層に配分して、各層の損傷及 び応答変形を算定している。これらの方法はいずれも、骨組への地 震入力エネルギーを算定し、地震入力エネルギーと構造物の吸収エ ネルギーの釣合関係から損傷予測するものであり、履歴型ダンパー 付骨組のようにダンパー部分の塑性変形の繰り返しによって多くの .地震エネルギーを吸収する構造物の損傷予測法を構築するには、エ
ネルギーの釣合の概念を用いた方法が適するものと思われる。

しかし、提案されているこれらの方法は、柱、梁より構成される ラーメン部分（以下、主体骨組と呼ぶ）を弾性として扱い、主に、各 層の履歴型ダンパーとそれを支持する部材で構成される部分 (以下、 ダンパー系と呼ぶ) に生じる損傷と各層の最大層間変形を予測する ものである。文献5）では、部分的に主体骨組が降伏する場合につい ても提案する予測方法の適用性を検討しているが、主体骨組に生じ る損傷を予測することを意図したものではない。

また、履歴型ダンパーに、より効果的にエネルギーを吸収させる ための適正耐力分担率》を考慮すれば、履歴型ダンパーを現行耐震 規定の許容応力度等計算における 1 次設計の地震荷重レベルよりも 小さな荷重で降伏させることが有効となるケースも考えられる。そ のような場合の、履歴型ダンパー付骨組の耐震安全性を評価するた めには、1 次設計の地震荷重レベルに相当する地震 (以下、中地震と 呼ぶ）に対して、履歴型ダンパー付骨組のダンパー系の損傷と骨組 各層の最大応答変形を予測する方法が必要である。文献8)では、こ のような場合のダンパー系の損傷や最大層間変形の予測法が示され ているが、中地震時における予測值と応答解析結果がどの程度対応 するのか、必ずしも明らかではない。

本論文で示す応答予測法も、骨組への地震入力エネルギーと構造 物の吸収エネルギーの釣合に基づく方法によって、履歴型ダンパー
本論の一部は，参考文献15)，16)に発表している。

*1 独立行政法人建築研究所構造研究グループ 主任研究負. 博士 (工学)

*2 国土交通省国土技術政策総合研究所住宅研究部 部長 $\cdot$ 工. 博

*3 国土交通省国土技術政策総合研究所建築研究部 室長·工修

*4 国土交通省国土技術政策綕合研究所建築研究部 主任研究官・博士(士学)

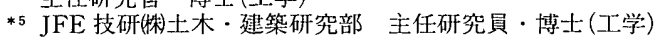

Senior Researcher, Structural Engineering Dept., Building Research Institute, Dr. Eng

Director, Housing Dept., National Institute for Land and Infrastructure Management (NILIM), Ministry of Land, Infrastructure and Transport (MLIT), Dr. Eng.

Head, Building Dept., NILIM, MLIT, M. Eng.

Senior Researcher, Building Dept., NILIM, MLIT, Dr. Eng.

Senior Researcher, Civil Engineering Research Dept., JFE R\&D Corp., Dr. Eng. 
付骨組の各層の損傷及び最大層間変形を予測するものである。しか し、本論文で提案する方法は、既往の予測法では考慮されていない 主体骨組の損傷についても予測可能なものである。また、本予測法 は、各層のダンパー系の塑性振幅の等価な繰り返し回数 $\left(d n_{1}\right)$ を用 いて、応答子測を行うものであり、中地震及び大地震それぞれで想 定される $d n_{1}$ の上限值及び下限值を用いることによって、地震波や骨 組の特性によって変化する骨組各層のダンパー系と主体骨組の損傷 及び各層の最大層間変形を安全側（大きめ）に予測しょうとするも のである。

本論文では、まず、骨組への地震入力エネルギーと構造物の吸収 エネルギーの釣合に基づく方法によって、中地震時にダンパーが塑 性化する履歴型ダンパー付鉄骨造骨組の中地震及び大地震時におけ る骨組各層のダンパー系、主体骨組の損傷及び最大層間変形角の予 測法を示す。次に、ダンパー付解析骨組による地震応答解析によっ て、上記 $d n_{1}$ のとり得る範囲（上限值及び下限值）を解析結果により 示す。また、このダンパー付解析骨組の地震応答解析結果と予測值 を比較することによって、本予測法の予測精度を明らかにするとと もに、既往の予測法による応答予測を行い、本予測法の予測精度と 比較する。最後に、1次設計の地震荷重レベルで塑性化する履歷型タ ンパーを有する鉄骨造試設計建物 (X方向5スパン、Y方向 3 スパン) を検討対象にして、予測值と地震応答解析結果を比較することに よって、本予測法の妥当性を確認する。

\section{2. 履歴型ダンパー付鉄骨造骨組の地震時応答予測法9)}

\section{1 骨組の損傷に寄与する地震入カエネルギーの計算}

骨組への地震入力を、損傷に寄与する地震入力エネルギー $\left(E_{D}\right)$ として与える。骨組の損傷に寄与する地震入力エネルギーに関して は、これまでに、地震応答解析を中心とした検討4)、10)、11)が行われ てきた。それらの検討結果から、本予測法では下式を用いて $E_{D}$ を計 算する。

$$
E_{D}=E_{e}+E_{p}=\frac{1}{2} M\left\{S_{v}\left(T_{e}\right)\right\}^{2}
$$

ここで $E_{e}$ は弾性歪みエネルギー、 $E_{p}$ は塑性歪みエネルギー、 $M$ は骨組 全質量、 $S_{v}$ は擬似速度応答スペクトル、 $T_{e}$ は骨組の塑性化の程度に よって定まる有効周期。 $S_{v}$ として、ここでは図1に示す建築基準法施 行令の限界耐力計算における第 1 種、 2 種、 3 種地盤で想定されてい る大地震及び中地震時の加速度応答スペクトルに $T / 2 \pi$ を乗じたもの を用いる。 $T$ は骨組の弾性 1 次固有周期。有効周期に関して、文献4) 及び 10）では、骨組の塑性化の程度や復元力特性に応じた有効周期

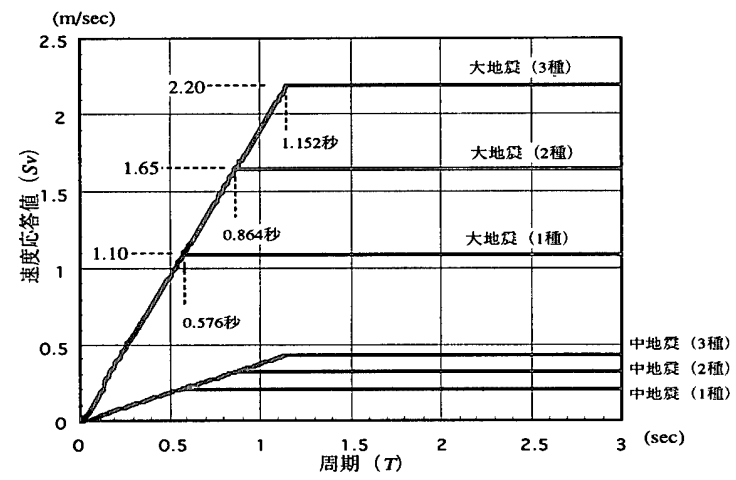

図 1 擬似速度応答スペクトル $\left(S_{v}\right)$
の計算方法が示されている。本予測法では、中地震でダンパーが塑 性化する骨組の有効周期を、簡便かつ安全側に評価する方法として、 中地震の骨組の有効周期については、骨組の降伏点割線剛性 $k_{e i}$ (図2 参照)によって計算される周期を用い、大地震時は、 $k_{e i}$ で算定される 周期を 1.2 倍することとした。1.2倍は、完全弾塑性型の復元力特性 の場合に、現実的な塑性化の程度を考慮して算定される值である4)。

\section{2 中地震時の骨組各層の損傷及び最大応答層間变形の予測法}

ここでは、図2に示すように、主体骨組とダンパー系それぞれを2 つの完全弾塑性型に置換したモデルによって応答予測を行う。本論 文の応答予測法では、文献3)のエネルギー吸収能力の高い要素を骨 組中に含む場合の、構造物の最大変形とエネルギー吸収能力の評価 式で示された、最大変形時のエネルギーの釣合の考え方に基づいて、 骨組の最大層間変形の予測を行う。

中地震における履歷型ダンパー付骨組の各層の最大層間変形 $\delta_{i}$ は、 (2) 式の施行令の $A_{i}$ 分布で計算される各層の設計用層せん断力 $Q_{i}$ に よって静的増分解析を行い、(3) 式で計算される各層の主体骨組の

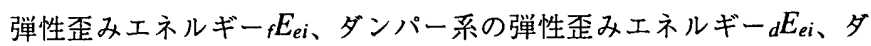
ンパー系のみが塑性変形している応答時 (主体骨組は弾性応答) の ダンパー系の塑性歪みエネルギー ${ }_{d} E_{1 p i}$ の和 $E_{1}$ が、(1) 式で計算され る中地震時のエネルギー $E_{D 1}$ と等しくなる場合として求められる。

$$
Q_{i}=C_{1} A_{i} \sum_{j=i}^{N} m_{j} g
$$

ここで $C_{1}$ は 1 階の地震層せん断力係数、 $N$ は骨組層数、 $m_{j}$ は $j$ 層の質 量、 $g$ は重力加速度。

$$
\begin{aligned}
& E_{1}=\sum_{i=1}^{N}\left({ }_{f} E_{e i}+{ }_{d} E_{e i}+{ }_{d} E_{1 p i}\right) \\
& { }_{f} E_{e i}=\frac{1}{2} f Q_{i f} \delta_{i} \\
& { }_{d} E_{e i}=\frac{1}{2}{ }_{d} Q_{u i d} \delta_{u i} \\
& { }_{d} E_{1 p i}=2\left({ }_{d} \delta_{i}-{ }_{d} \delta_{u i}\right){ }_{d} Q_{u i} \cdot{ }_{d} n_{1}
\end{aligned}
$$

ここで $Q_{i}$ は $i$ 層に $Q_{i}$ の水平力が作用しているときの $i$ 層の主体骨組 に作用するせん断力、 $\delta_{i}$ 及び ${ }_{d} \delta_{i}$ はそのときの主体骨組及びダンパー 系の $i$ 層の層間変形で、 ${ }_{f} \delta_{i}={ }_{d} \delta_{i}=\delta_{i}$ である (図2参照)。d $Q_{u i}$ は $i$ 層の夕゙ ンパー系の降伏耐力、 $d \delta_{u i}$ はダンパー系降伏時層間変形。d $n_{1}$ は次式で 定義されるダンパー系の塑性振幅 $\left({ }_{d} \delta_{i}-{ }_{d} \delta_{u i}\right)$ の等価な繰り返し回数 であり、文献 4) で示される等価履歴ループの繰り返し数 $n_{e q}$ の 2 倍

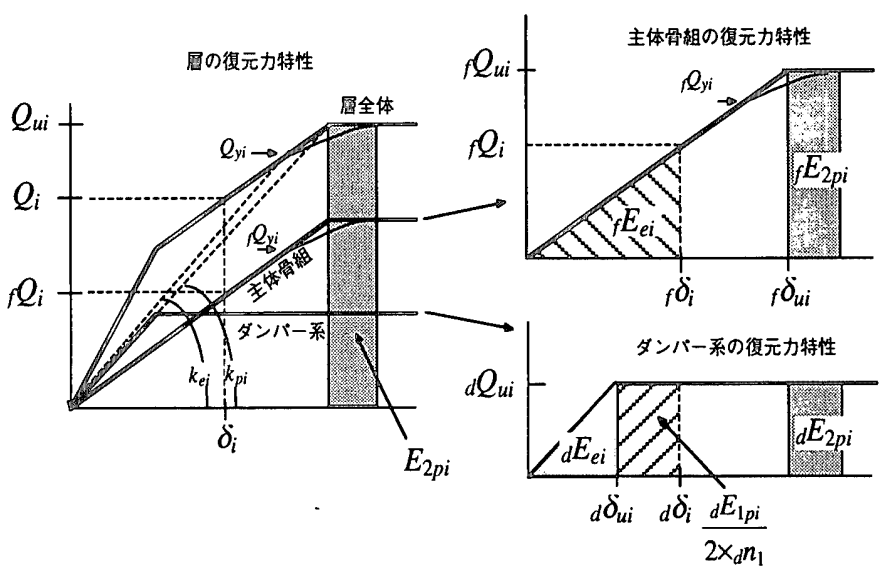

図 2 主体骨組とダンパー系の復元力特性模式図 
の值である。

$$
{ }_{d} n_{1}=\bar{\eta}_{i} /\left({ }_{d} \mu_{\text {maxi }}-1\right)
$$

${ }_{d} \bar{\eta}_{i}$ は下式で表されるi層のダンパー系の正負の平均累積塑性変形倍 率、 ${ }^{2} \mu_{\text {maxi }}$ 層のダンパー系の最大塑性率で、ダンパー系の層間変形 ${ }_{d} \delta_{i}$ をダンパー系の降伏時層間変形 $d \delta_{u i}$ で除した值。

$$
{ }_{d} \bar{\eta}_{i}=\frac{1}{2} \cdot \frac{{ }_{d} E_{1 p i}}{{ }_{d} Q_{u i d} \delta_{u i}}
$$

${ }_{d} n_{1}$ は、後述するダンパー付解析骨組の地震応答解析結果から、中 地震ではお捄よそ2 10 となる。本予測法では、各層の応答変形 $\delta_{i}$ を安全側（大きめ）に評価するため、便宜的に、 ${ }^{2} n_{1}$ の下限近傍の值 である 2 を用いて、（6）式のダンパー系の塑性歪みエネルギー ${ }_{d} E_{1 p i}$ を計算する。このような計算により、中地震の各層の最大層間変形 が求められる。

一方、地震応答中に主体骨組が保持する弾性歪みエネルギー $E_{e i}$ の 一部は、地震終了時には、残留変形がほとんどなくなることにより、 ダンパー系の塑性歪みエネルギー ${ }_{d} E_{1 p i}$ として消費されていると考え られる5)。そこで、本予測法では、ダンパー系の塑性歪みエネルギー ${ }_{d} E_{1 p i}$ は、便宜的に、 ${ }_{d} n_{1}$ の上限近傍の值である 10 を使って、(6) 式に よって ${ }_{d} E_{1 p i}$ を別途計算し、ダンパー系の損傷を安全側（大きめ）に 評価する。このようにして、本予測法では、地震波や骨組の特性に よって変化する骨組各層の応答変形及びダンパー系と主体骨組の揊 傷を安全側に予測しょうとするものである。なお、中地震でダン パー系が塑性化しない場合は、（6）式の計算は不要であり、（5）式 では、ダンパー系に作用するせん断力と変形によって ${ }_{d} E_{e i}$ を計算す る。

\section{3 大地震時の骨組各層の損傷及び最大忍答層間変形の予測法}

大地震時の骨組の損傷に奇与する地震入力エネルギー $\left(E_{D 2}\right)$ も、 中地震同様、(1) 式で計算する。大地震時においては、(2) 式の設 計用層せん断力 $Q_{i}$ で静的増分解析を行い、最初に主体骨組が降伏す る時点（以下、損傷限界時と呼ぶ）の各層の層せん断力 $\left(Q_{i}^{\text {elim }}\right)$ と 変形 $\left(\delta_{i}^{\text {elim }}\right)$ を求め、それらを使って、(3) 〜 (6) 式によって、骨 組全体の損傷限界時までの吸収エネルギー $\left(E_{2}^{\text {elim }}\right)$ を求める。大地 震時の ${ }_{d} n_{1}$ は、後述の地震応答解析からおおよそ5〜20となる。最大 層間変形を予測するために $E_{2}^{\text {lim }}$ を計算する際には、前述の中地震の 場合と同様に、大地震の ${ }^{2} n_{1}$ の下限近傍の值である 5 を使う。

この $E_{2}^{\text {elim }}$ は、大地震時のダンパー付骨組の応答において、主体骨 組が塑性化していない応答時に骨組が吸収するエネルギーを表すも のである。したがって、主体骨組が塑性化している応答時に骨組の 吸収するべきエネルギー $E_{2 p}$ は、 $E_{D 2}-E_{2}^{e l i m}$ で計算される。dn1の下限近 傍の值の 5 を使って、 $E_{2}^{\text {elim }}$ 計算することによって、E $E_{2 p}$ が大きめに計 算され、骨組全体の変形や主体骨組の損傷が安全側（大きめ）に評 価される。

$E_{2 p}$ は、秋山により提案された骨組各層への損甥配分の式4)におい て、最適せん断力係数分布 $\overline{\alpha_{i}}$ を $A_{i}$ 分布とした次式によって各層に配 分する。

$$
E_{2 p i}=\frac{S_{i} P_{i}^{n}}{\sum_{j=1}^{N} S_{j} P_{j}^{n}} E_{2 p}
$$

$$
\begin{aligned}
& S_{i}=\left(\sum_{j=i}^{N} \frac{m_{j}}{M}\right)^{2} A_{i}\left(\frac{k_{p 1}}{k_{p i}}\right) \\
& P_{i}=\frac{\alpha_{i}}{\alpha_{1} A_{i}}
\end{aligned}
$$

$k_{p i}$ は図 2 に示す骨組の保有水平耐力点割線剛性、 $\alpha_{i}$ は $i$ 層の降伏層せ 几断力係数。

$n$ は損傷集中指数であり、文献 12）の結果より、柱崩壊型は 8 、梁 崩壊型は 4 とする。履歴型ダンパー付骨組では、柱及び梁が、おお むね弾性応答するものと考えられ、梁崩壞型と同様に損傷が集中し にくい構造形式として $n=4$ とする。

（9）式で計算される各層の塑性歪みエネルギー $E_{2 p i}$ は、ダンパー 系と主体骨組の耐力比に比例して、次式でダンパー系 $\left.{ }_{d} E_{2 p i}\right)$ と主 体骨組 $\left({ }_{f} E_{2 p i}\right)$ それぞれに配分される。

$$
\begin{aligned}
& { }_{d} E_{2 p i}=E_{2 p i} \times\left({ }_{d} Q_{u i} / Q_{u i}\right) \\
& { }_{f} E_{2 p i}=E_{2 p i} \times\left(Q_{u i} / Q_{u i}\right)
\end{aligned}
$$

大地震時のダンパー系の塑性歪みエネルギー ${ }_{d} E_{p i}$ は、上記 ${ }_{d} E_{2 p i}$ とダ ンパー系だけが塑性変形している応答時のエネルギー ${ }_{d} E_{3 p i}$ の和とし て計算される。

$$
{ }_{d} E_{p i}={ }_{d} E_{2 p i}+{ }_{d} E_{3 p i}
$$

なお、 $E_{3 p i}$ は次式で計算される。

$$
{ }_{d} E_{3 p i}=2\left({ }_{d} \delta_{i}^{\text {elim }}-{ }_{d} \delta_{u i}\right){ }_{d} Q_{u i} \cdot{ }_{d} n_{1}
$$

ここで ${ }_{d} \delta_{i}^{\text {elim }}$ は、損倁限界時の $i$ 層のダンパー系の層間変形で ${ }_{d} \delta_{i}^{e l i m}=\delta_{i}^{e l i m}{ }_{0}{ }_{d} E_{3 p i}$ を計算する時の ${ }_{d} n_{1}$ は、中地震時のダンパー系の 損傷と同様に、大地震の ${ }_{d} n_{1}$ の上限近傍の值である 20 を使って、ダン パー系の損傷を安全側（大きめ）で計算する。

履歴型ダンパー付骨組の大地震時の $i$ 層の最大層間変形 $\delta_{\max i}$ は、 主体骨組の層の平均累積塑性変形倍率 $f \bar{\eta}_{i}$ を用いて次式で計算する。

$$
\begin{aligned}
& \delta_{\text {maxi }}=\left(\frac{{ }_{f} \bar{\eta}_{i}}{{ }_{f}}+1\right){ }_{f} \delta_{u i} \\
& { }_{f} \bar{\eta}_{i}=\frac{1}{2} \cdot \frac{{ }_{f} E_{2 p i}}{{ }_{f} Q_{u i f} \delta_{u i}}
\end{aligned}
$$

ここで $n_{1}$ は、大地震時の主体骨組の塑性振幅の等価な繰り返し回数 であり、（7）式と同様に定義される。ここでは文献 12）及び4）の 解析結果から、2 とする。f $\delta_{u i}$ は図 2 に示す主体骨組の保有水平耐力時 の変形。

履歴型ダンパー付骨組では、ダンパーのエネルギー吸収効果に よって、 $E_{D 2}-E_{2}^{e l i m} の$ 計算值が負になる場合がある。これは主体骨組 が塑性化しないことを意味し、(9) 式以後の計算は不要となる。こ の場合、中地震時の場合と同様に静的増分解析によって、(4) (6)

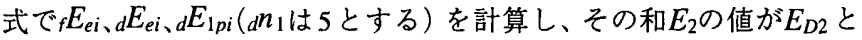
等しくなる時点として、各層の最大層間変形 $\delta_{\operatorname{maxi}}$ が計算される。各 層のダンパー系の塑性歪みエネルギーは、（6）式を用いて、この変 形 $\delta_{\text {maxi }}\left({ }_{d} \delta_{i}=\delta_{\text {maxi }}\right)$ と大地震の ${ }_{d} n_{1}$ の 上限近傍の值である 20 を使っ て、安全側（大きめ）に計算される。

3. 履歴型ダンパー付解析骨組の地震応答解析と応答予測 ここでは、中地震でダンパーが塑性化するような履歴型ダンパー 
付骨組の、大地震及び中地震それぞれにおけるダンパー系の塑性振 偪の等価な繰り返し回数 $\left({ }_{d} n_{1}\right)$ を明らかにするために、ダンパー付 解析骨組の地震応答解析を行い、各層のダンパー系の平均累積塑性 変形倍率 $\left({ }_{d} \bar{\eta}_{i}\right)$ と最大塑性率 $\left({ }_{d} \mu_{\text {maxi }}\right)$ の関係を調べる。また、こ こで設定したダンパー付解析骨組について、予測值と地震応答解析 結果を比較することによって、本予測法の予測精度を明らかにし、 さらに、既往の予測法による応答予測を行い、本予測法の予測精度 と比較する。

\section{1 解析骨組の設定と解析方法}

解析骨組は、図 3 で示す 8 層 1 スパンのラーメン骨組の各層にブ レース型のダンパーを組み込んだダンパー付骨組である。この検討 では、主体骨組の各層の剛性 $\left(f k_{i}\right)$ に対するダンパー系の各層の剛 性 $\left({ }_{d} k_{i}\right)$ の比 $\left(d k_{i} / k_{i}\right)$ とダンパー系の降伏耐力を解析パラメーター として、 ${ }_{d} k_{i} / k_{i}$ を 0.5、1.0、2.0、3.0 とし、ダンパー部材として $100 \mathrm{~N} /$ $\mathrm{mm}^{2}$ 級と $225 \mathrm{~N} / \mathrm{mm}^{2}$ 級の鋼材を用いた座屈拘束ブレースを仮定する ことによって、合計 8 種類のダンパー付骨組を設定する。ここでは、 解析骨組のダンパー系、主体骨組それぞれに完全弾塑性型の復元力 特性を仮定して、せん断型モデルによる地震応答解析を実施する。 解析骨組の名称は、例えば $d k_{i} / k_{i}$ が 0.5 で、 $100 \mathrm{~N} / \mathrm{mm}^{2}$ 級ダンパーの 骨組は、DM-05-100 と表示する。

主体骨組の各層の剛性、耐力には、文献 12) で設定した 8 層 1 ス パンの梁崩壊型ラーメン骨組の各層の剛性と耐力を用いた。文献12) の骨組の $A_{i}$ 分布の層せん断力による静的增分解析から得られる各層 の荷重 - 変形関係を図 4 に示し、表 1 に図 4 から得られる各層の剛性 $\left(f k_{i}\right)$ と最大曲率点における耐力 $\left(f Q_{u i}\right)$ を示す。

解析骨組のダンパー部材の断面は、主体骨組の各層の剛性に対す るダンパー系の各層の剛性の比 $\left({ }_{d} k_{i} / k_{i}\right)$ が $0.5 、 1.0 、 2.0 、 3.0$ とな

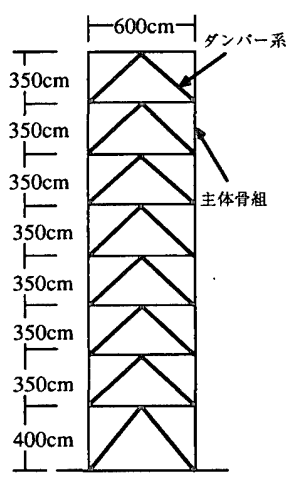

図 3 解析骨組

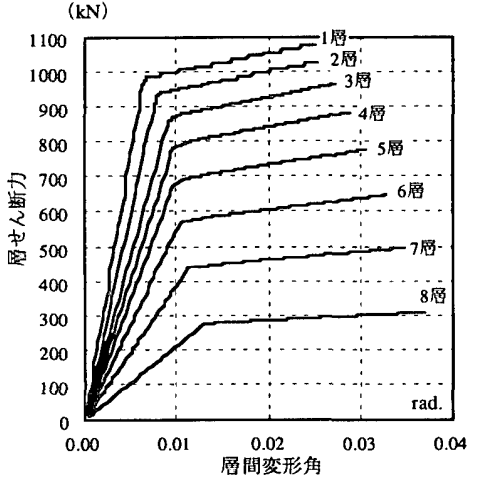

図4 文献 12) の骨組の荷重 - 変形関係
表 1 主体骨組の各層の剛性、耐力及び解 析骨組のダンパー系/主体骨組耐力比

\begin{tabular}{|c|c|c|c|c|c|}
\hline 層 & $\begin{array}{l}\text { 各層 } \\
\text { 重量 } \\
(\mathrm{t})\end{array}$ & 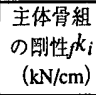 & $\begin{array}{c}\text { 主体骨組の } \\
\text { 的力f } Q_{u i} \\
(\mathrm{kN})\end{array}$ & $\begin{array}{c}\text { 解析骨組 } \\
\text { DM-05-100 } \\
\text { Sd } Q_{u i l} / \mathcal{Q}_{u i}\end{array}$ & $\begin{array}{l}\text { 解析骨組 } \\
\text { DM-30-225 } \\
\text { のd } Q_{u i l} f_{f} Q_{u i}\end{array}$ \\
\hline 8 & 33.6 & 61.2 & 274.4 & 0.028 & 0.388 \\
\hline 7 & 33.6 & 111.2 & 440.0 & 0.032 & 0.441 \\
\hline 6 & 33.6 & 158.6 & 573.3 & 0.035 & 0.482 \\
\hline 5 & 33.6 & 201.1 & 686.0 & 0.037 & 0.511 \\
\hline 4 & 33.6 & 233.3 & 785.0 & 0.038 & 0.518 \\
\hline 3 & 33.6 & 271.6 & 860.4 & 0.040 & 0.550 \\
\hline 2 & 33.6 & 342.3 & 938.8 & 0.046 & 0.635 \\
\hline 1 & 33.6 & 384.3 & 989.8 & 0.058 & 0.795 \\
\hline
\end{tabular}

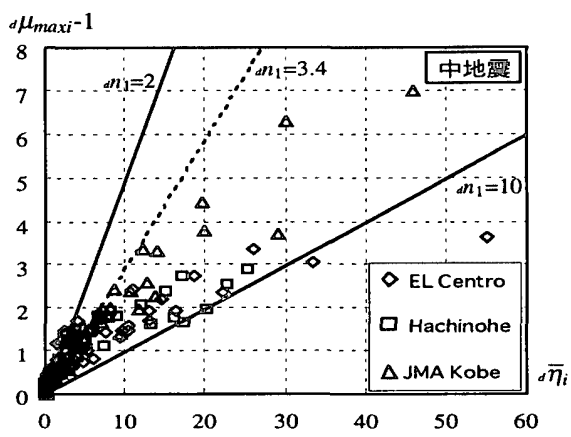

図 5 中地震及び大地震に対するダンパー系の $\bar{\eta}_{i}$ と ${ }_{d} \mu_{\operatorname{maxi}}-1$ の関係
るように、 $k_{i} / k_{i}$ に応じて、幾何学的な線形関係から決定する。ここ では、ダンパーとしての塑性変形区間をダンパー系の芯-芯距離の半 分とし、ダンパー支持部分（接合部分）の断面積はダンパーの断面 積の 2 倍と仮定して、ダンパーの断面積を決めている。ここで設定 した解析骨組では、各層のダンパー系と主体骨組の耐力比 $\left.{ }_{d} Q_{u i} /{ }_{f} Q_{u i}\right)$ は一定ではない。各層の ${ }_{d} Q_{u i} /{ }_{f} Q_{u i}$ の例として、DM-05-100 骨組と、DM-30-225 骨組の場合を表 1 に示す。なお、各解析骨組の ${ }_{d} Q_{u i} / f Q_{u i}$ の值は、ダンパー部材の降伏応力度及び $k_{i} / k_{i}$ の值に比例 したものとなる。

応答解析における減衰は、Rayleigh 型で 1 次及び 2 次の減衰定数 を 0.01 とし、数値積分には Newmark $\beta$ 法 $(\beta=1 / 4)$ を用い、時間刻 みは $1 / 200$ 秒とする。入力地震動は、El Centro NS、Hachinohe EW、 JMA Kobe NSの3つであり、地霞動継続時間はそれぞれ、53.7 秒、 35.9 秒、 30.0 秒である。解析時間を 100 秒とし、地震動入力終了後 に自由振動させて弾性振動エネルギーを0に収束させる。解析毎に、 解析時間中の $E_{e}+E_{p}$ の最大応答值が、図 1 で示す第 2 種地盤の $S_{v}$ を 使って (1) 式で計算される值に一致するように、入力地震動の最大 加速度を調整して解析を行う。なお、解析終了時の $E_{p}$ でなく、 $E_{e}+E_{p}$ の最大応答值を用いているのは、弾性応答に近い場合との連続性を

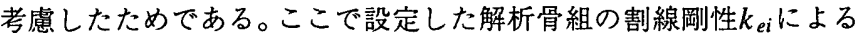
固有周期は、 1.01 秒 1.23 秒の範囲であり、図 1 より、解析骨組の $S_{v}$ は、中地震では $33 \mathrm{~cm} / \mathrm{sec} 、 大$ 大地震では $165 \mathrm{~cm} / \mathrm{sec}$ となる。 3.2 ダンパー系の平均累榬塑性変形倍率と最大塑性率の関係 ダンパー系の塑性振幅の等価な繰り返し回数 $\left({ }_{d} n_{1}\right)$ は、地震応答 解析から得られる骨組各層のダンパー系の平均累積塑性変形倍率と

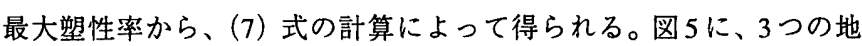
震動に対する 8 種類の解析骨組の各層のダンパー系の ${ }_{d} \bar{\eta}_{i}$ と ${ }_{d} \mu_{\text {maxi }}-1$ の関係を示す。左が中地震、右が大地震の結果である。本予測法で 用いている』施は、地震時にダンパーのみが塑性化している応答時の ダンパーの塑性振幅の等価な繰り返し回数を表している。そこで、 大地震の図では、主体骨組が塑性化した64プロットを除いて表示し ている（全プロット数は 8 骨組 $\times 8$ 層 $\times 3$ 地震波 $=192$ である）。中地 震では主体骨組は塑性化していないので全プロットの表示である。 この図から、中地震に扔けるd和はおおよそ2 10、大地震ではおお よそ5〜20の範囲に分布している。中地震の ${ }_{d} n_{1}$ の平均值は 3.4、大 地震は7.7であり、それらを図中に点線で示している。また、直下型 の地震動であるJMA Kobeのプロットは、d $n_{1}$ が小さい範囲に分布する 傾向が見られる。

\section{3 各骨組の予測値と応答解析の比較}

ここで設定した $8 \supset の$ 解析骨組は、各層に同一の剛性比 $\left(d k_{i} / k_{i}\right)$ 
のダンパーを配置している。DM-20-100骨組を対象にして、本予測 法による予測值と地震応答解析を比較した結果を図 6 に示す。中地 震、大地震の最大層間変形角、ダンパー系の ${ }_{d} \bar{\eta}_{i}$ 、大地震の主体骨組 のF $\bar{\eta}_{i}$ について比較している。ダンパー系については、 ${ }^{2} n_{1}$ の上限値と 参照値としての下限值による予測值をプロットしている。

中地震及び大地震の最大層間变形角の予測㯰は、3波の地震動によ る応答のばらつきの上限の傾向を比較的精度よく予測している。た だし、大地震の JMA Kobe の応答では、上層部で応答值が予測值を 超過する部分がある。ダンパー系の各層の $d_{i}$ については、中地震、 大地震ともに、3地震波による応答の值は、 $d n_{1}$ の下限値と上限值で計

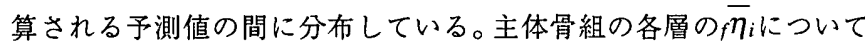
は、JMA Kobeでは上層部に損傷が生じているが、El Centroと Hachinohe の各層の損傷は 0 となり、予測值も0に近い值となった。 これ以外の 7つの骨組の結果の概要を以下に記述する。中地震の 最大層間変形角については、各骨組とも 3 地震波の応答のばらつき は少なく、予測值はそれぞれの骨組の応答の傾向を精度よく予測し た。大地震の最大層間変形角は、ここで示したDM-20-100骨組の結 果と同様に、JMA Kobeの応答では、応答值が予測值を超過する部分 が見られたが、El Centro と Hachinohe の応答值のばらつきの上限の 傾向はおおよそとらえることができた。ダンパー系のd搹について は、中地震、大地震ともに、 ${ }^{2} k_{i} /{ }^{\prime} k_{i}$ が大きい設定 (2.0と 3.0) の骨組 では、応答值の分布が、d $n_{1}$ の下限值で計算した予測值の分布に近く、 ${ }_{d} k_{i} / k_{i}$ が小さい設定 (1.0 と 0.5) の骨組では、応答值の分布は、 ${ }^{2} n_{1}$ の上限值で計算した予測值の分布に近づく傾向が見られた。主体骨 組の $\bar{\eta}_{i} に つ い て は 、 d k_{i} /$ t $k_{i}$ が2.0以上の骨組では、JMA Kobeの一部 の層で応答值が予測值を超過し、El Centro と Hachinohe での応答值 は 0 となり、予測值も 0 に近い值となった。d $k_{i} / k_{i}$ が 1.0 以下の骨組 でも、JMA Kobeの一部の層で応答值が予測值を超過したが、おおよ そ 3 波の応答のばらつきの上限を予測した。

\section{4 本予測法による予測值の精度}

本法による予測值の予測精度を明らかにするために、ここで解析 した 8 骨組の中地震と大地震に対する各層の最大層間変形角、ダン パー系と主体骨組の平均累積塑性変形倍率に関して、予測值を綐軸 に、応答解析結果を横軸にしてプロットした結果を図7 (a) 〜 (e) に示す。また、これらの予測值の応答解析值に対する比の平均と変 動係数を計算した結果を表 2 に示す。なお、表 2 の計算では、最大層
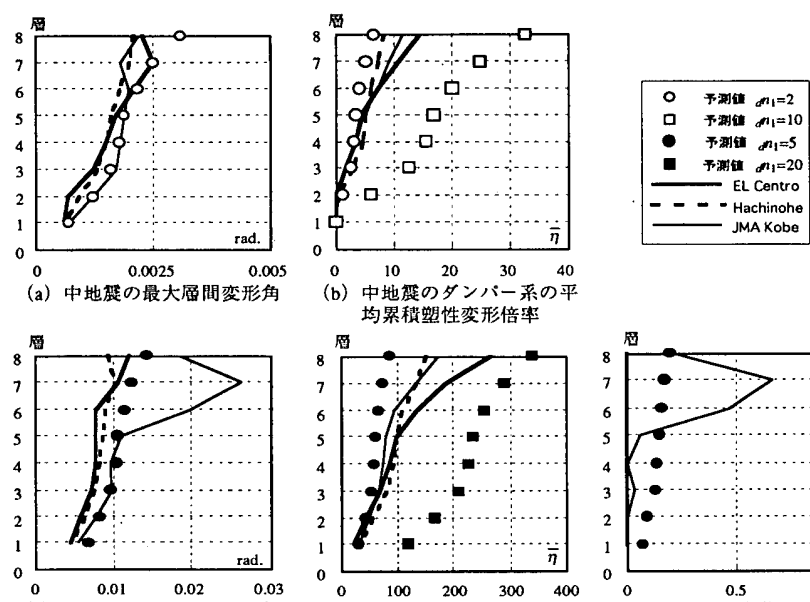

(c) 大地破の最大酋間変形角 (d) 大地震のタンバー系の
均累程塑性変形倍草

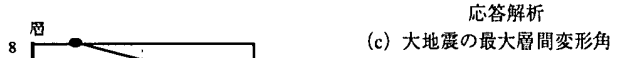

間変形角については全デー夕を対象に計算し、平均累積塑性変形倍 率については、ダンパー系は応答解析の結果の ${ }_{d} \bar{\eta}_{i}$ が 1 以上、主体骨 組は、的 $\bar{i}_{i} 0.1$ 以上のデー夕を対象にして計算している。

図7及び表 2 から、最大層間変形角に関しては、中地震及び大地震 の（予測值/応答解析）の平均が、1.08 と 1.04 であり、最大層間変 形角の予測值は、応答解析結果のおおよそ平均に対応していること がわかる。ただし、JMA Kobeの地震動に対する応答解析值は、予測 值よりも大きくなる傾向が見られる。

ダンパー系の $\bar{\eta}_{i}$ に関しては、中地震の予測值は、図7 (b) で示す ように、応答解析值のばらつきの上限をやや大きめに予測する傾向 となり、大地震の予測值は、図 7 (d) で示すように、EL Centroの一 部を除き、予測值に対する応答解析值のばらつきの上限近傍を予測 する傾向となっている。また、中地震、大地震ともに、 $\bar{\eta}_{i}$ が大きく なるにしたがい、(予測值/応答解析)の值は 1 に近づく傾向が見られ る。表 2 の（予測値/応答解析）の平均は、中地震で 3.55 、大地震で 2.73 となっている。本予測法は、ダンパー系の損賃を安全側に予測 するために、図5で示した $n_{1}$ のばらつきの上限值を用いて全ての骨 組のダンパーの損傷を計算している。図 5 で示す ${ }_{d} n_{1}$ の平均値によっ て、大地震のダンパーの ${ }_{d} \bar{\eta}_{i}$ を予測すると、(予測值/応答解析) の平 均は 1.06 (変動係数 0.63）になるが、前述のとおり、本論では、ダン パー系の損傷を安全側に予測することを意図して、d $n_{1}$ の上限值により 予測することを提案する。

主体骨組の $\bar{\eta}_{i}$ は、予測值の応答解析值に対する比の平均は 1.70 で あり、応答解析結果を大きめに予測する傾向がある。また、变動係 数は 0.88 であり、最大層間変形角やダンパー系の值に比べて大きな 值となっている。

\section{5 既往の予測法との比較}

既往の研究等で提案されている予測法によって、ここで設定した

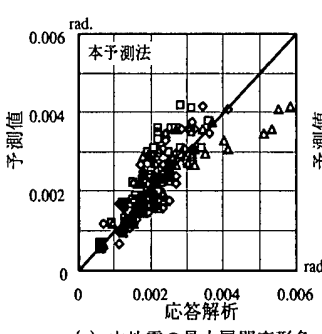

(a) 中地震の最大層間変形角

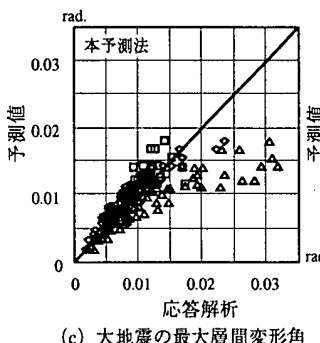

図 7 本予測法の予測值と応答解析の関係（全データ）
図 6 DM-20-100 骨組の予測值と応答解析の比較

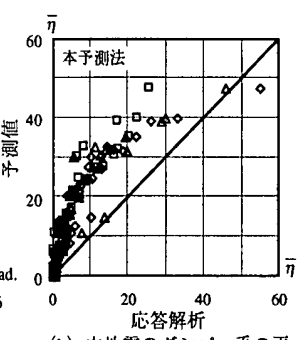

(b) 中地祳のタンバーー䒺の平

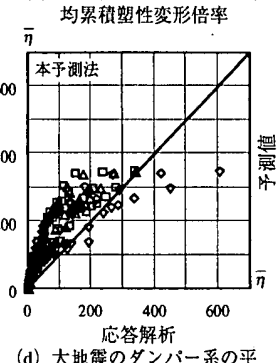

大地霞のタンパー系の平 大地霞のタンバー柔の

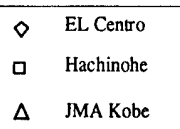

$\Delta \quad$ JMA Kobe

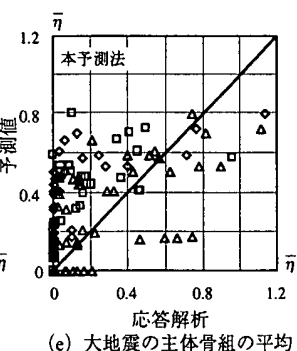

(e) 大地霞の主体骨組の平均 累積馍性変形倍事
表2 本予測法の (予測値/応答解析) の平均と変動係数

\begin{tabular}{|c|c|c|c|c|c|}
\hline & \multicolumn{2}{|c|}{ 最大居間変形角 } & \multicolumn{3}{|c|}{ 平均異积塑性変形倍率 } \\
\hline & 中地酵 & 大地霞 & $\begin{array}{l}\text { 中地震タ } \\
\text { ンバー番 }\end{array}$ & $\begin{array}{l}\text { 大地震多 } \\
\text { ンバ矛 }\end{array}$ & $\begin{array}{c}\text { 大地麗 } \\
\text { 主体骨組 }\end{array}$ \\
\hline 平均 & 1.08 & 1.04 & 3.55 & 2.73 & 1.70 \\
\hline 変動 & 0.22 & 0.24 & 0.51 & 0.64 & 0.88 \\
\hline
\end{tabular}




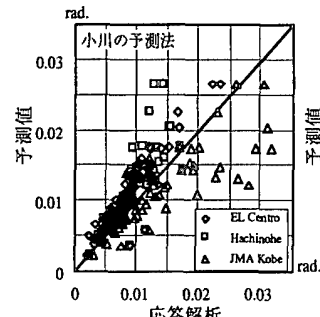

(a) 大地震の较大層間変形角

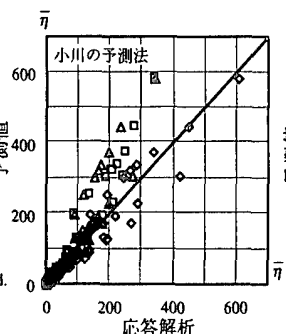

(b) 大地霞のダンバー系の平 大地累皘㙰性変形倍率

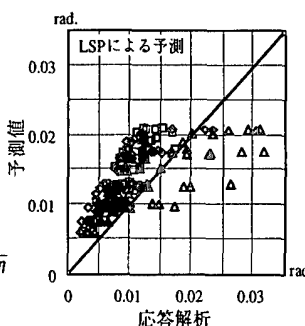

(c) 大地震の取大層間変形角
図 8 既往の予測法による予測值と応答解析の関係（全データ）

表 3 各予測法の（予測值/応答解析）の平均之変動係数

\begin{tabular}{|c|c|c|c|c|c|}
\hline & \multicolumn{3}{|c|}{ 大地浱の取大居問変形角 } & \multicolumn{2}{|c|}{ 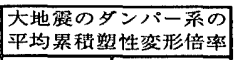 } \\
\hline & LSP & 小川 & 本予測法 & 小川 & 本予測法 \\
\hline 平均 & 1.50 & 1.18 & 1.04 & 1.14 & 2.73 \\
\hline 変醇 & 0.31 & 0.27 & 0.24 & 0.31 & 0.64 \\
\hline
\end{tabular}

$8 つ の$ 解析骨組の応答予測を行い、本法の予測值の精度と比較する。 既往の予測法として、ここでは、地震時の履歷型ダンパー付骨組の 各層のダンパー系の損傷と最大層間変形角を予測する方法として、 小川らの提案した予測法 ${ }^{5)}$.8) 及び地震時の骨組各層の最大層間変形 を予測する方法として、米国 のFEMA-273'13)のLinear Static Procedure （LSP）で示されている方法、の2つを取りあげる。LSPは、変位一 定則の考え方に基づく方法であり、(18) 式によって、設計用加速度 応答スペクトルを用いて建物全体の地震力 $(V)$ を計算し、その地震力 に基づいて骨組の静的弾性解析を行い、得られる各層の層間变形を 弾塑性時の最大層間変形とする方法である。

$$
V=C_{1} C_{2} C_{3} S_{a} W
$$

ここで $C_{1}$ は静的弾性解析により計算される変形と予測される弾塑性 変形を関係づける係数、 $C_{2}$ は復元力特性の形態等から決まる係数、 $C_{3}$ はP- $\Delta$ 効果による係数である。 $S_{a}$ は設計用加速度応答スペクトルで、 ここでは図1で示した2種地盤の擬似速度応答スペクトルの元となっ た加速度応答スペクトルを用いる。Wは骨組全重量。

この2つの予測法による予測值と応答解析結果の関係を、図 8 (a) 〜 (c) に示す。(a)、（b）は、小川の予測法による大地震時の各層 の最大層間変形角とダンパー系の平均累積塑性変形倍率、(c) はLSP

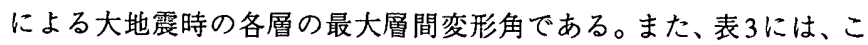
の 2 つ予測法による予測值及び本法の予測值の応答解析值に対す る比の平均と変動係数を比較して示す。

図 8 及び表3からは、大地震の最大層間変形角に関しては、本予測 法の（予測值／応答解析）の平均が 1.04 で、他の 2 つの方法に比べて 最も 1 に近く、変動係数も 0.24 で最も小さいことがわかる。大地震の ダンパー系の平均累積塑性変形倍率に関しては、小川の予測法は、 （予測值/応答解析）の平均が1.14であり、本予測法は2.73である。前 節で述べたように、本予測法はダンパー系の損傷の予測值に対する応 答值のばらつきの上限近傍を予測する傾向があるため、小川の予測法 に比べ、大きな値になっている。また、変動係数も本予測法は 0.64 で あり、小川の予測法の 0.31 に比べ、大きな值である。本法の変動係数 が比較的大きいのは、骨組特性等により变化する ${ }^{2} n_{1}$ を、一定值で予測 するためと考えられる。小川の予測法は、地震波によって変動する応 答の平均を近似するものである5)が、図8(b) からは、d融が大きい範 囲では、ばらつきの上限を近似する傾向になっている。これは、こ の解析では $d \bar{\eta}_{i}$ が大きい層では、主体骨組にも損傷が生じる場合が多
くなるのに対して、小川の方法ではタンパー系のみに損傷が生じる ものとして計算するためと推測される。

\section{4. 履歴型ダンパー付試設計建物の地震応答解析}

中地震で降伏する座屈拘束ブレース型の履歴型ダンパーを有する 4 層、8層、12 層の試設計鉄骨造建物を検討対象にして、本論文の応 答予測法による予測值と地震応答解析結果を比較することによって、 予測法の妥当性を確認する。

\section{1 履歴型ダンパー付鉄骨造建物の概要}

試設計建物は、現行耐震規定の許容応力度等計算を満足するように 設計された文献 2）の履歴型ダンパー付建物のダンパーを、225 N/mm 級の鋼材から $100 \mathrm{~N} / \mathrm{mm}^{2}$ 級の鋼材に変えることによって、中地震時より ダンパーのエネルギー吸収効果を発揮させることを意図した建物であ る。図9に、検討の対象にした $4 、 8 、 12$ 層の履歴型ダンパー付鉄骨造 建物のうち、4層建物の平面図と軸組図を示す。 $8 、 12$ 層建物も同様の 平面、軸組である。角形鋼管柱と $\mathrm{H}$ 形鋼大梁からなるラーメン骨組の センターコア部の X、Y 方向 4 構面に、座屈拘束ブレース型の履歷型 ダンパーを配置したものである。ダンパーの軸材には $100 \mathrm{~N} / \mathrm{mm}^{2}$ 級の鋼 材を用いる。柱脚は固定とする。これらの3つの建物の設計条件や各 部材断面等の詳細は、文献2)、8）を参照されたい。

\section{2 解析方法}

$1 つ の$ 建物について、X、Y 方向それぞれで解析モデルを設定する。 解析モデルは、ダンパー付の構面とラーメン構面を而端ピンの仮想の 剛梁で接続したものであり ${ }^{2)}$ 、一般化硬化ヒンジ法を用いた平面骨組解 析プログラム ${ }^{14)}$ を使って解析を行う。解析モデルの名称は、例えば、 4 層 X 方向モデルの場合は、D4X と表記する。

解析モデルの柱、梁、履歴型ダンパーの復元力特性は、歪硬化 $2 \%$ の バイリニア型、接合部パネルは弾性としている。各層重量は、柱梁節 点に支配面積に応じて集中させる。減衰は剛性比例型で、1次モードに 対する減衰定数を 0.02 とする。数值積分には Newmark $\beta$ 法 $(\beta=1 / 4)$ を用い、時間刻みは $1 / 200$ 秒とする。

入力地震動には El Centro NS、Hachinohe EW、JMA Kobe NS（いず れも継続時間 20 秒) を用いる。解析モデル毎に、解析時間中の $E_{e}+E_{p}$ の最大応答値が、図 1 の第 2 種地盤の $S_{v}$ を使って (1) 式で計算され
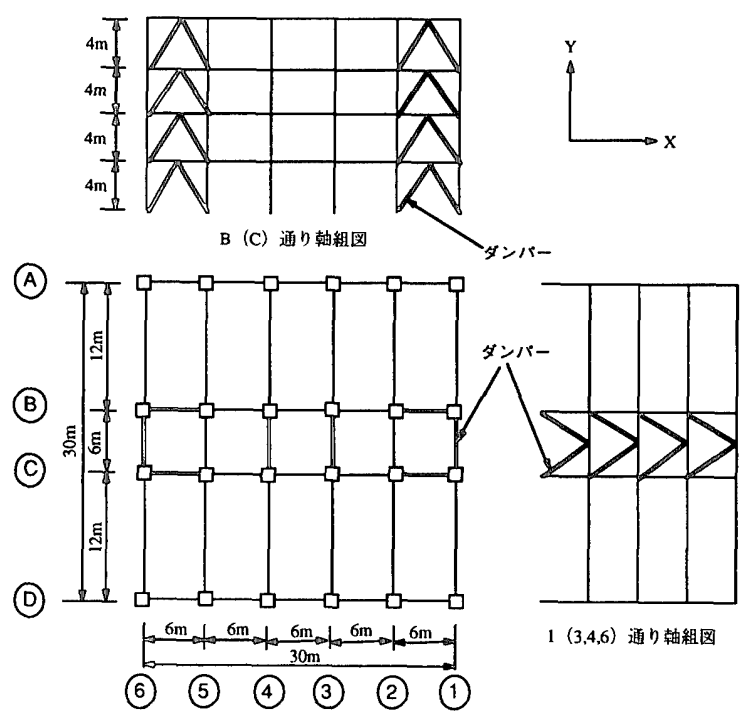

図 9 履歴型ダンパー付試設計建物の平面及び軸組図 
表4 各解析モデルの入力地震動の最大加速度及び骨組特性

\begin{tabular}{|c|c|c|c|c|c|c|c|c|c|c|c|c|}
\hline 解析モデル名称 & \multicolumn{2}{|c|}{ D4X } & \multicolumn{2}{|c|}{ D4Y } & \multicolumn{2}{|c|}{ D8X } & \multicolumn{2}{|c|}{ D8Y } & \multicolumn{2}{|c|}{$\mathrm{D} 12 \mathrm{X}$} & \multicolumn{2}{|c|}{ D12Y } \\
\hline 入力地楚動 & 中地嘼 & 大地燳 & 中地症 & 大地麗 & 中地䃌! & 大地簏 & 中地垔! & 大地赈 & 中地瑟 | & 大地䀼 & 中地震! & 大地霆 \\
\hline El Centro NS (gal) & 121 & 573 & 132 & 523 & 130 & 789 & 130 & 780 & 206 & 869 & 193 & 869 \\
\hline Hachinohe EW (gal) & 91 & 314 & 96 & 322 & 55 & 340 & 54 & 362 & 100 & 389 & 113 & 369 \\
\hline JMA Kobe NS (gal) & 95 & 545 & 118 & 501 & 116 & 663 & 117 & 688 & 123 & 823 & 129 & 847 \\
\hline 降伏点割線岡山性固有猿期 & \multicolumn{2}{|c|}{$0.87 \mathrm{sec}$} & \multicolumn{2}{|c|}{$0.86 \mathrm{sec}$} & \multicolumn{2}{|c|}{$1.49 \mathrm{sec}$} & \multicolumn{2}{|c|}{$1.55 \mathrm{sec}$} & \multicolumn{2}{|c|}{$1.87 \mathrm{sec}$} & \multicolumn{2}{|c|}{$2.01 \mathrm{sec}$} \\
\hline 終局ベースシャー係数 & \multicolumn{2}{|c|}{0.35} & \multicolumn{2}{|c|}{0.47} & \multicolumn{2}{|c|}{0.29} & \multicolumn{2}{|c|}{0.32} & \multicolumn{2}{|c|}{0.24} & \multicolumn{2}{|c|}{0.24} \\
\hline 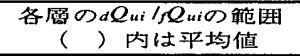 & \multicolumn{2}{|c|}{$\begin{array}{c}0.26 \sim 0.56 \\
(0.43)\end{array}$} & \multicolumn{2}{|c|}{$\begin{array}{c}0.14 \sim 0.35 \\
(0.26)\end{array}$} & \multicolumn{2}{|c|}{$\begin{array}{l}0.12 \sim 0.59 \\
(0.44)\end{array}$} & \multicolumn{2}{|c|}{$\begin{array}{c}0.10 \sim 0.49 \\
(0.36)\end{array}$} & \multicolumn{2}{|c|}{$\begin{array}{c}0.05 \sim 0.54 \\
(0.36)\end{array}$} & \multicolumn{2}{|c|}{$\begin{array}{c}0.05 \sim 0.53 \\
(0.34)\end{array}$} \\
\hline 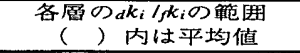 & \multicolumn{2}{|c|}{$\begin{array}{c}0.78 \sim 3.69 \\
(2.16)\end{array}$} & \multicolumn{2}{|c|}{$\begin{array}{c}0.65 \sim 2.79 \\
(1.71)\end{array}$} & \multicolumn{2}{|c|}{$\begin{array}{c}0.32 \sim 3.56 \\
(2.00)\end{array}$} & \multicolumn{2}{|c|}{$\begin{array}{l}0.22 \sim 4.35 \\
(2.14)\end{array}$} & \multicolumn{2}{|c|}{$\begin{array}{l}0.10 \sim 2.26 \\
(1.25)\end{array}$} & \multicolumn{2}{|c|}{$\begin{array}{c}0.04 \sim 2.74 \\
(1.37)\end{array}$} \\
\hline
\end{tabular}
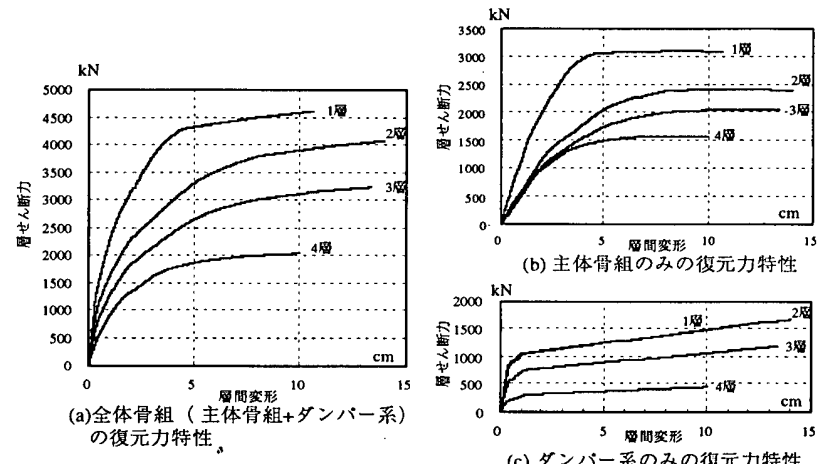

(b) 主体骨組のみの得元力特性

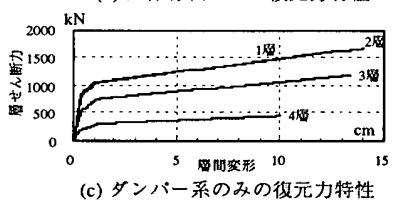

(c) ダンバー系のみの役元力特性

図 10 静的増分解析から得られる荷重 - 変形関係 (D4X)

る值に一致するように、入力地震動の最大加速度を調整して解析を行 う。6つの解析モデルの降伏点割線剛性 $k_{e i}$ による固有周期は 0.86 秒 $\sim 2.01$ 秒であり、第 2 種地盤での $S_{v}$ は、中地震 $33 \mathrm{~cm} / \mathrm{sec}$ 、大地震 $165 \mathrm{~cm} /$ $\sec$ となる。各モデルの中地震及び大地震の入力地震動の最大加速度及 び骨組基本性能を表 4 に示す。

6つの解析モデルの応答予測值の計算のために、各モデルの静的増 分解析を行い、応答予測の計算に必要となる值を求める。その 1 例 として、図10に、D4Xの静的增分解析から得られる(a) 全体骨組、 （b）主体骨組、(c) ダンパー系、それぞれの各層の層せん断力-層間 変形関係を示す。ここでのダンパー系の層せん断力は、全体骨組の 層せん断力から主体骨組の各層の柱に生じるせん断力を引いたもの である。

\section{3 予測值と応答解析結果の比較}

図11〜15に、Y方向のモデルの応答予測值と地震応答解析結果を 比較して示す。図11は中地震による各層の最大層間変形角の結果で
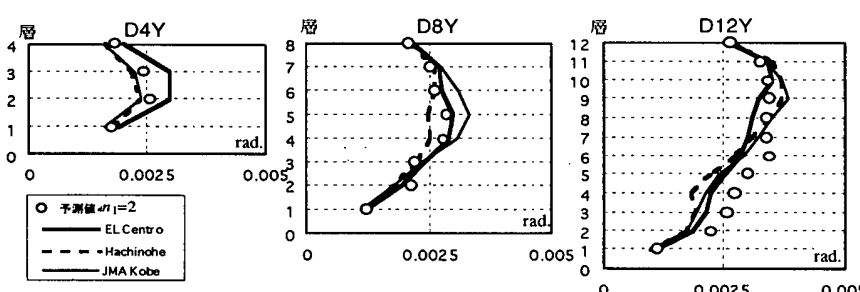

図 11 中地震の最大層間変形角の分布
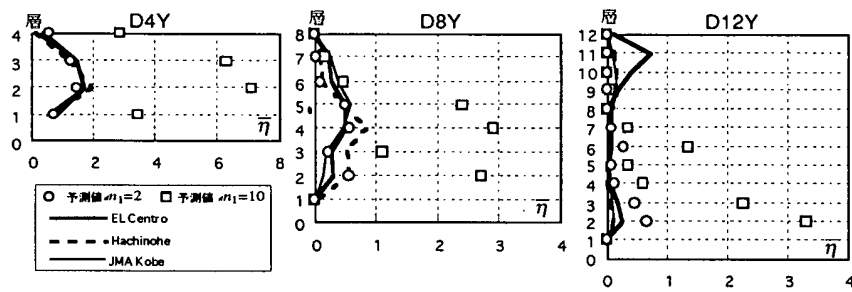

図 12 中地震のダンパー系の平均累積塑性変形倍率の分布
ある。3地震波による応答変形のばらつきは小さく、予測值は 3 波の 応答值の傾向を精度よく表している。図 12 は中地震によるダンパー 系の各層の平均累積塑性変形倍率 ${ }_{d} \bar{\eta}_{i}$ である。予測値は $d n_{1}$ の上限値と 参照值としての下限值それぞれに対する計算値をプロットしている。 これらの解析モデルでは、応答解析による各層の ${ }_{d} \bar{\eta}_{i}$ は、d $n_{1}$ の下限值 で計算した予測值の近くに分布している。

図13は大地震による各層の最大層間変形角の結果である。予測值 の分布は、3地震波による応答のばらつきの上限の分布の傾向を比較 的精度よく表している。図 14 は大地震によるダンパー系の各層の平 均累積塑性変形倍卑 $d \bar{\eta}_{i}$ である。予測值は ${ }^{2} n_{1}$ の上限值と参照値として の下限值それぞれに対する計算值をプロットしている。4層モデルで は、3地震波による応答解析の值は、 $d n_{1}$ の下限值と上限值で計算され る予測値の間に分布している。8層及び 12 層モデルでは、応答解析 の值は、d $n_{1}$ の下限值で計算した予測値に近くなっている。図 15 は大 地震による主体骨組の各層の平均累積塑性変形倍率 $\bar{\eta}_{i}$ である。各層の 応答解析の $\bar{\eta}_{i}$ は、梁に生じた塑性歪み土ネルギーを上下層に半分づつ 配分して計算している。なお、柱はいずれのモデルにおいても塑性化 していない。これらのモデルの予測值は、3波の応答の上限值に比べ、 安全側の評価となっている。なお、X方向の解析モデルに関しても、Y 方向と同様の傾向となっている15)、16)。
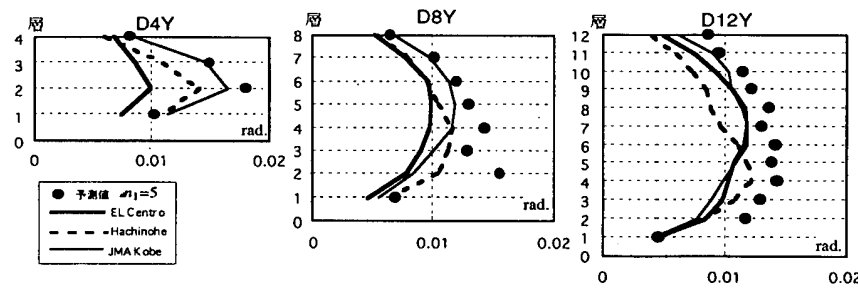

図 13 大地震の最大層間変形角の分布
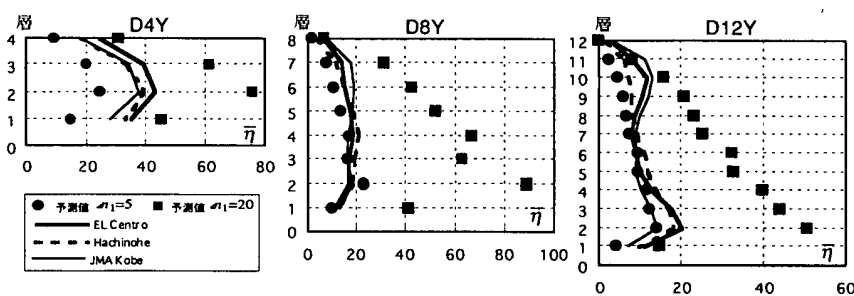

図 14 大地震のダンパー系の平均累積塑性変形倍率の分布
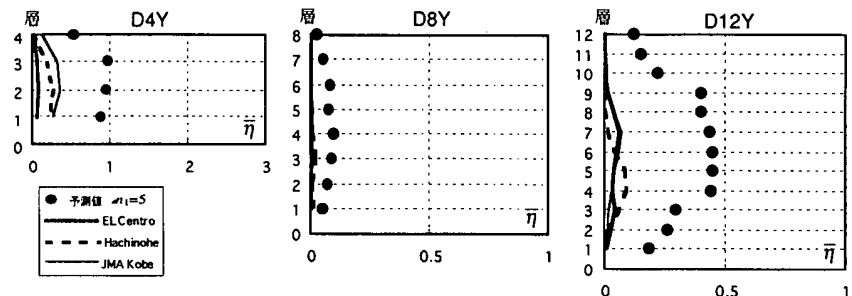

図 15 大地震の主体骨組の平均累積塑性変形倍率の分布 


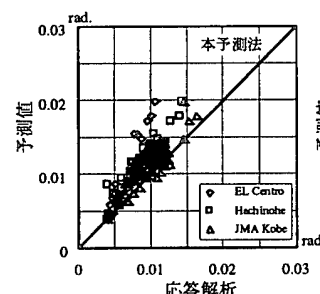

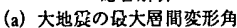

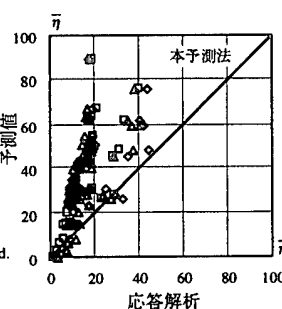

(b) 大地筑のタンバー系の平

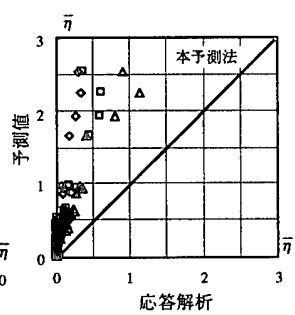
(c) 大地艿の主体骨組の平均
累税塑性変形倍率
図 16 本予測法の予測値と応答解析の関係（全データ）

表 5 各予測法の（予測值/応答解析）の平均と変動係数

\begin{tabular}{|c|c|c|c|c|c|c|}
\hline & \multicolumn{3}{|c|}{ 大地筑の㔀大啳間変形角 } & \multicolumn{2}{|c|}{ 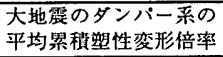 } & \multirow{2}{*}{ 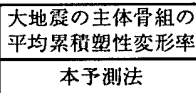 } \\
\hline & LSP & 小川 & 本予測法 & 小川 & 本予測法 & \\
\hline 平均 & 1.75 & 1.03 & 1.25 & 1.06 & 2.41 & 4.31 \\
\hline 変動 & 0.21 & 0.17 & 0.18 & 0.24 & 0.41 & 0.42 \\
\hline
\end{tabular}

図 16 (a) 〜 (c) に、ここで対象にした解析モデルの、大地震に対 する各層の最大層間変形角、ダンパー系、主体骨組の平均累積塑性変 形倍率について、本法の予測值と応答解析結果の関係を示す。また、 3 章と同様に、LSP、小川の予測法によって、これらの解析モデルの 応答予測を行い、本予測法の予測精度と比較した結果を表 5 に示す。

図16から、本予測法では、大地震の最大層間変形角、ダンパー系、 主体骨組の損傷に関して、概ね安全側で予測が行われていることが わかる。表 5 から、これらの解析モデルに対しては、小川の予測法 による最大層間変形角、ダンパー系の平均累積塑性変形倍率の、(予 測值／応答解析）の平均が最も 1 に近いのがわかる。また、表 3 の結 果に比べて、全体に変動係数が小さくなっている。

試設計建物を対象にしたこれらの解析結果から、本予測法では、 $d n_{1}$ の上限值及び下限值を用いることによって、骨組各層の最大層間変形 角、ダンパー系及び主体骨組の損傷を、概ね安全側で予測できること が確認された。

\section{5. まとめ}

本論文では、エネルギーの釣合に基づく履歴型ダンパー付鉄骨造 骨組の地震時応答予測法を示した。この予測法は、中地震時にダン パーが塑性化する骨組も対象とするものであり、各層のダンパー系 の塑性振幅の等価な絽り返し回数 $\left(d n_{1}\right)$ を考慮して応答予測を行う。 本予測法は、中地震及び大地震それぞれで想定される ${ }^{2} n_{1}$ の上限值及 び下限值を用いることによって、地震波や骨組の特性によって変化 する骨組各層のダンパー系と主体骨組の損傷及び各層の最大層間变 形を安全側に予測しょうとするものである。

本予測法で用いるダンパー系の塑性振幅の等価な繰り返し回数 $\left(d n_{1}\right)$ を、ダンパー付解析骨組の地震応答解析によって明らかにし た。その結果、中地震のd的はおおよそ2 10、大地震ではおおよう 5〜20の範囲であった。また、このダンパー付解析骨組の応答解析 結果と予測值を比較して、本予測法の予測精度を明らかにするとと もに、既往の予測法による応答予測を行って、予測精度を比較した。 その結果、大地震の最大層間变形角に関しては、予測值の応答解析 值に対する比の平均が、既往の $2 つ$ つ予測法に比べて、最も 1 に近く なった。一方、大地震のダンパー系の平均累積塑性変形倍率に関して は、本法の予測值は、応答解析值のばらつきの上限近傍を予測する 傾向を有し、既往の予測法と比較すると、予測值の応答解析值に対
する比の平均は大きくなっている。

中地震で塑性化する履歴型ダンパーを有する $4 、 8 、 12$ 層の現実的 な鉄骨造試設計建物を検討対象にして、各層の最大層間変形角、ダ ンパー系と主体骨組の平均累積塑性変形倍率に関して、予測値と応答 解析結果を比較し、本子測法の妥当性を確認した。

なお、中地震及び大地震のダンパー系の損傷 $d \bar{\eta}_{i}$ が、d$n_{1}$ の下限值で の予測值に近くなるか、上限值による予測値に近くなるかは、骨組 各層の ${ }_{d} Q_{u i} / f Q_{u i}{ }_{d} k_{i} / k_{i} k_{i}$ 、終局べースシヤー係数、骨組層数、等の骨 組特性が関係するものと考えられる。今後の課題として、中地震及 び大地震時のダンパー系の ${ }_{d} n_{1}$ と上記パラメータの定量的関係を明確 にする必要があり、それによって、より合理的な応答予測を行うこ とが可能となる。

\section{【謝辞】}

この論文の履歴型ダンパー付解析骨組の地震応答解析では、熊本 大学小川厚治教授が作成された shearms.fを使わせていただきまし た。ここに記して謝意を表します。

\section{参考文献}

1）黄一華、和田章、岩田衛：履歴型ダンパーを有する被害レベル制御構造、 構造工学論文集、Vol.40B、pp.221 234、1994.3

2）加村久哉、河村昌俊、小川厚治、井上一朗：許容応力度等計算に準起して 設計された履歷型ダンパー付鋼構造骨組の地震応答、日本銅構造協会 銅構 造論文集、Vol.10、No.38、pp.91 104、2003.6

3）原田幸博、秋山宏：エネルギ集中型柔剛混合骨組の耐震設計、日本建築学 会構造系論文集、第 472 号、pp.57～66、1995.6

4）秋山宏:エネルギーの釣合に基づく建築物の耐震設計、技報堂出版、1999.11

5）小川厚治、平野智久：履歴型ダンパーの必要塑性变形性能に関する研究、 日本建築学会構造系論文集、第 558 号、pp.197～204、2002.8

6）辻井剛、小倉桂治、高山正春、辻田修、木村雄一：履歷減衰部材を有する 架構の耐震設計、シンポジウム「耐震設計の一つの新しい方向、pp.273〜 276、1995.10

7）井上一朗、小野聡子：履歷ダンパーの適正耐力分担率と架構の設計耐力、 構造工学論文集、Vol.41B、pp.9 15、1995.3

8）履歴型ダンパー付銅構造骨組の設計法、建築研究所/日本鉄銅連盟市場セ ンター共同研究報告書、2002.2

9）西山功、向井昭義、長谷川隆、石原直：エネルギーの釣合に基づく建築物 の実用的な耐震設計法のフレームワークの提案、鉄構技術、Vol.16、 No.184、pp.28 35、2003.9

10) 小川厚治、井上一朗、中島正愛: 損傷に寄与する地震入力エネルギーに関 する考察、日本建築学会構造系論文集、第 530 号、pp.177 184、2000.4

11）井上一朗：鋼構造の柎震設計の原点、建贸技術、No.619、pp.112 119、 2001.9

12）長谷川隆:エネルギーの釣合に基づく鉄骨構造骨組の地震応答予測法に関 寸る検討、日本建築学会大会学術講演梗概集、C-1、pp.837 838、2002.8

13) FEMA-273 NEHRP Guidelines for the Seismic Rehabilitation of Buildings. Federal Emergency Management Agency、1997.10

14）小川厚治、多田元英：柱・梁接合部パネルの変形を考虑した静的・動的応 答解析プログラムの開発、第 17 回情報システム利用技術シンポジウム、 pp.79 84、1994.12

15）長谷川隆、西山功、向井昭義、石原直、加村久哉：エネルギーの釣合に基 づ履歴型タンパー付鉄骨造骨組の地震時損傷予測(その1 予測方法の提 案と解析骨組による検討)、日本建築学会大会学術講演梗概集、C-1、 pp.645 646、2003.9

16）加村久哉、長谷川隆、西山功、向井昭義、石原直：エネルギーの釣合に基 づく履歴型ダンパー付鉄骨造骨組の地震時損傷予測 (その2 試設計建物に よる検証)、日本建築学会大会学術講演梗概集、C-1、pp.647 648、2003.9

（2003年 8 月18日原稿受理，2004年 4 月23日採用決定） 